\title{
MULTIPLE MYELOMA. IV. ABNORMAL SERUM COMPONENTS AND BENCE JONES PROTEIN ${ }^{1}$
}

\author{
BY R. WAYNE RUNDLES, GERALD R. COOPER, AND ROBERT W. WILLETT 2 \\ (From the Department of Medicine, Duke University School of Medicine and the Hematology \\ Laboratory, Duke Hospital, Durham, N. C.)
}

(Submitted for publication April 4, 1951; accepted July 20, 1951)

The overgrowth of plasma cells in multiple myeloma is associated with a unique abnormality in the synthesis of protein. Abnormal components occur in the sera of patients with this disease, sometimes in sufficient amount to produce hyperproteinemia, and the majority excrete Bence Jones protein in the urine.

The relation between plasma cell proliferation and the production of the abnormal proteins, and the relation of the serum components to Bence Jones protein have been obscure. The degree of hyperproteinemia and the amount of Bence Jones protein excreted in the urine vary greatly in patients who appear to have equally progressive and anatomically extensive disease. Large amounts of abnormal protein have been present in the sera of patients with, as well as without, Bence Jones proteinuria, and vice versa. The anomalous serum and urinary proteins vary from patient to patient in electrophoretic mobility, solubility in salt solution, molecular weight and antigenicity (1-11).

It has been suggested that the serum increments in multiple myeloma, especially those with gamma globulin characteristics, may represent antibodies to Bence Jones protein (12). On the other hand, the serum components, which are produced in all likelihood by the abnormal plasma cells $(9,13)$ may represent a perversion in the normal processes of globulin production (14-16). As to the origin of Bence Jones proteins, compounds of such relatively small molecular size are readily excreted by the kidney $(17,18)$. Large concentrations have not been found in the serum (5). Bence Jones proteins could possibly be derived from the abnormal serum constituents, since the latter have a molecular size about three to six times as great

\footnotetext{
${ }^{1}$ Supported by a grant from the American Cancer Society upon recommendation of the Committee on Growth of the National Research Council.

2 Damon Runyon Clinical Research Fellow.
}

$(3,5,12)$, if the latter were to disintegrate or be split into protein moities filterable through the glomeruli. An additional possibility should not be overlooked, namely, that the proliferating plasma cells might produce more than one type of abnormal protein.

A series of 30 patients with multiple myeloma have been studied, many of them as the activity of their disease was suppressed by therapy and later as relapse occurred, in the investigation of these problems.

\section{MATERIALS AND METHODS}

Sera were collected and studied by electrophoresis using barbital buffer at $\mathrm{pH} 8.6$ as previously described $(9,19)$.

Urine specimens were tested for the presence of protein with $20 \%$ sulfosalicylic acid. When proteinuria was present, 24-hour collections of urine were made under toluene at room temperature and the specimens stored at $4^{\circ} \mathrm{C}$. The total protein content was determined by the precipitation method previously described (9). Qualitative tests for Bence Jones protein included 1 ) testing the protein at a concentration of $0.1-0.4 \%$ for coagulation below $60^{\circ} \mathrm{C}$. at $\mathrm{pH} 5.5$ in urine or, after electrophoretic separation, diluted in $0.9 \% \mathrm{NaCl}$ solution, and 2) testing for solubility at $100^{\circ} \mathrm{C}$. followed by reprecipitation on cooling. To demonstrate solubility of the protein at the boiling temperature further acidification with acetic or nitric acid was usually necessary. To purify and concentrate urinary proteins for physico-chemical studies, the refrigerated urine specimens were decanted to remove inorganic precipitates and pooled into suitable quantities. The $\mathrm{pH}$ was adjusted to 5.5 with acetic acid and ammonium sulfate slowly added to a final concentration of $60 \%$ saturation. The supernatant fluids gave negative tests for protein with sulfosalicylic acid after the salt precipitation. The protein precipitate was separated off by centrifugation and dialyzed at $5-8^{\circ} \mathrm{C}$. against water until essentially free of ammonium ion. The protein solutions were stored in a frozen state if not used at once. Electrophoretic analyses of the urine proteins were carried out as for the serum specimens.

Diffusion studies of the serum and urinary proteins were made in the Tiselius apparatus in which boundaries were recorded by the method of crossed slits described by Svensson. At the conclusion of the electrophoresis runs, if large peaks of suitable dimension were present, as in 
Figure 1, the current was turned off and photographs taken at intervals of six to 12 hours. A minor degree of boundary asymmetry was sometimes present. The photographs were enlarged and drawn. The peak boundaries and base lines were drawn through the vertical midpoints of the Philpot-Svensson patterns.

Three formulae, incorporating the maximum ordinate and the maximum ordinate-area methods, were used for calculating diffusion rates (20).

$$
\begin{aligned}
D & =F \frac{\mu^{2}}{2 t} \\
D & =F \frac{A^{2}}{4 \pi \mathrm{Hm}^{2} \mathrm{t}} \\
D & =F \frac{\mathrm{A} \mu}{\sqrt{8 \pi} \mathrm{Hmt}}
\end{aligned}
$$

where

$\mathrm{t}=$ time of diffusion in seconds

$\mathrm{Hm}=$ maximum ordinate of peak

$\mu=$ one-half the horizontal distance between the points of inflection of the vertical sides of the peak, equal to $\frac{\mathrm{Hm}}{\sqrt{\epsilon}}$ or $\frac{\mathrm{Hm}}{1.649}$

$$
F=\left(\frac{1}{\text { Magnification }}\right)^{2}
$$

$$
=\left[\begin{array}{l}
\frac{1}{\begin{array}{l}
\text { Magnification } \\
\text { of Tiselius } \\
\text { apparatus }
\end{array}} \times \frac{1}{\begin{array}{l}
\text { Magnification } \\
\text { of projector } \\
\text { for drawing }
\end{array}}
\end{array}\right]^{2}
$$

$\mathrm{A}=$ area of peak determined by standardized planimeter.

Diffusion rates were calculated from the average of the three methods for both the ascending and descending sides of the electrophoretically separated protein components. The two values were averaged.

$\mathrm{D}_{20, \mathrm{w}}$ was calculated by correcting the observed diffusion rate for the influence of temperature and the relative viscosity of the barbital buffer, 1.065 (Neurath [20], equation 46, p. 384).

$D_{20,}^{\infty}$ w was calculated by correcting for the influence of protein concentration on diffusion rate. This correction was made for each individual component by multiplying $\mathrm{D}_{20, \mathrm{w}}$ by the relative viscosity of the average protein concentration on the two sides of the diffusing peak (see Neurath [20], equation 48). The protein concentration data were available from the preceding electrophoretic analysis. The specific viscosity of albumin was assumed to be 0.04 , globulin 0.06 , serum containing over $40 \%$ albumin 0.05 , and serum with albumin less than $40 \% 0.06$ (Neurath, Cooper and Erickson [21]). The diffusion of sucrose in a $2 \%$ solution in barbital buffer at $\mathrm{pH} 8.6$ on two occasions were $D_{1}^{\circ}, w=24.1$ and 22.7 , compared to the average value determined by Gosting and Morris (22) of 23.83 ( $\times 10^{-7}$ ). The diffusion of purified beef serum albumin (Armour) on three occasions was $D_{20, w}^{\infty}=6.4,6.5$ and 6.0. The average of 13 calculations of the diffusion of human albumin in the sera studied was $\mathrm{D}_{20, \mathrm{w}}^{\infty}=6.8 \pm 0.4$.

After completing the electrophoretic and diffusion measurements, the buffer solution was removed from the de-

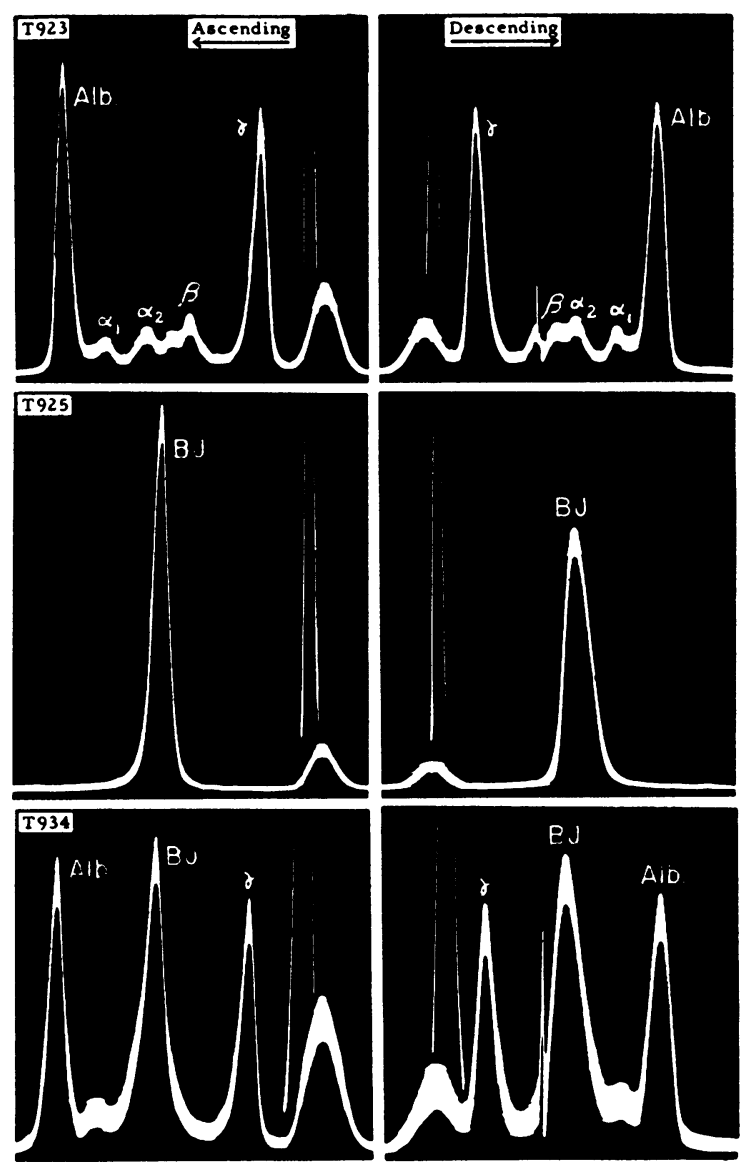

Fig. 1. Case 1, A. R., C19679. Photographs of Electrophoretic Patterns of Serum and Urinary Proteins

T923, serum during relapse; T925, Bence Jones protein from urine; T934, mixture of serum and urinary protein.

scending side of the Tiselius cell above the peak representing the abnormal gamma or " $\mathrm{M}$ " component. The latter was then removed under visual control and studied in the ultracentrifuge using the same buffer as employed in electrophoresis and diffusion. The sedimentation analyses were performed with the electrically driven, Model E, Ultracentrifuge built by the Specialized Instruments Corporation, as described by Schwert (23). Boundary displacements were measured by enlargement of the Philpot-Svensson photographs. The log of the distance from the center of rotor $(x)$ was plotted against time in seconds $(t)$. The uncorrected sedimentation constant $\left(S_{t}\right)$ was calculated from

$$
\mathrm{S}_{\mathrm{t}}=\frac{\mathrm{dx} / \mathrm{dt}}{\omega^{2} \mathrm{x}}
$$

or on integration

$$
S_{t}=2.3026 \frac{\Delta \log x}{\omega^{2} \Delta t}
$$

where $\omega$ is speed in radians/sec. and $\mathrm{dx} / \mathrm{dt}$ is $\mathrm{cm} . / \mathrm{sec}$. 
The sedimentation constant in water at $20^{\circ} \mathrm{C}$. $\left(\mathrm{S}_{20, \mathrm{w}}\right)$ was calculated by the method of Svedberg and Pedersen (24) (eq. 63, p. 36). The relative viscosity of the barbital buffer used was 1.065 . The specific molal volume of the protein was taken to be 0.75 in all cases. The density of the barbital buffer at $30^{\circ} \mathrm{C}$. was 0.0079 above water.

$\mathbf{S}_{20, \text { w }}^{\infty}$ was computed as suggested by Lauffer (25) by multiplying $S_{20,}$ w by the relative viscosity of the protein solution. The latter was taken as 1 plus the specific viscosity of the protein component multiplied by protein concentration.

The molecular weight of the proteins was computed from the sedimentation and diffusion values as follows (24):

$$
\text { Mol. wgt. }=\frac{\mathrm{RTS}_{20, \mathrm{w}}}{\mathrm{D}_{20, \mathrm{w}}\left(1-\mathrm{V}_{\left.\rho_{20, \mathrm{w}}\right)}\right.}=9.696 \times 10^{4} \times \frac{\mathrm{S}_{20, \mathrm{w}}}{\mathrm{D}_{20, \mathrm{w}}}
$$

where

$$
\begin{aligned}
\mathrm{R} & =\text { gas constant, } 8.313 \times 10^{7} \\
\mathrm{~T} & =\text { absolute temperature } \\
\mathrm{V} & =\text { assumed to be } 0.750 \\
\rho_{2, \mathrm{Q}} \mathrm{W} & =\text { density of water at } 20^{\circ} \mathrm{C} .=0.9982
\end{aligned}
$$

\section{OBSERVATIONS}

The major physico-chemical data relating to the abnormal serum and urinary proteins in the individual patients with multiple myeloma are given in Table $I$. Their correlation with the severity and anatomic extent of the myelomatous disease, renal function, and other relevant data is summarized below. Additional clinical and therapeutic information in some cases has been reported elsewhere, as indicated.

Case 1. A. R., C19679. This patient was observed over a period of more than three years $(9,26,27)$. Her serum contained an abnormal component of gamma mobility that fluctuated from 4.0 to $1.4 \mathrm{gm}$. per $100 \mathrm{cc}$. as the activity of her disease was modified by urethane therapy. During a relapse $18 \frac{1}{2}$ months after the initial treatment, the gamma protein concentration in her serum was $3.0 \mathrm{gm}$. per $100 \mathrm{cc}$. (Table I, T745). The Bence Jones protein excretion at this time was 2-3 gm. per day. Four months later the serum component was reduced to 1.4 gm. per $100 \mathrm{cc}$. and the proteinuria to $0.3-0.5 \mathrm{gm}$. During subsequent relapses gamma protein increased to 2.7 and $3.6 \mathrm{gm}$. per $100 \mathrm{cc}$. and the urinary protein ranged from 6-10 gm. per day. Inulin and p-aminohippurate clearance studies on three occasions showed moderate impairment of renal function (28).

Electrophoretic studies of the protein from pooled urine specimens collected during the ninth and 19th-24th months of observation showed an almost pure homogeneous protein (Figure 1, T925). The mobility of the abnormal serum component was 1.2, that of the protein in the urine, 3.8. To study the effect of different media on electrophoretic mobility, protein from the urine was added to her serum and the electrophoresis repeated. The urinary protein separated from the gamma component of the serum and had the mobility of alpha 2 globulin, 2.9 (Figure 1, T934).

The diffusion rate of the gamma component in the serum, measured in the Tiselius apparatus after electrophoresis, was $D_{20, w}^{\infty}=4.9$. When removed and studied in the
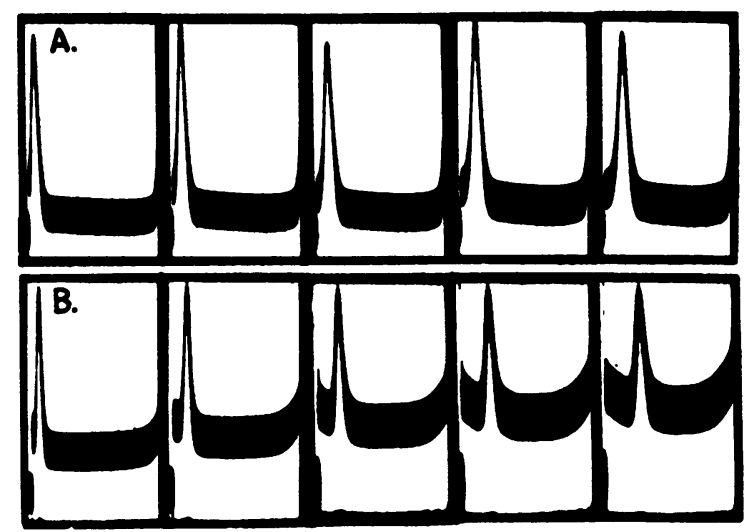

Fig. 2. Case 1, A. R., C19679. Photographs at Eight Minute Intervals of Ultracentrifuge SediMENTATION BOUNDARIES

A, Bence Jones urinary protein; B, gamma protein separated after electrophoresis (T923, Figure 1).

ultracentrifuge, it sedimented as one component, $S_{\mathbf{2}, w}^{\infty}=$ 6.6 (Figure 2,B). The molecular weight was calculated at 130,000 . The diffusion and sedimentation rates of the urinary protein were 6.7 and 2.80 , respectively, and its calculated molecular weight, 40,300 .

Case 7. A. A. P., 59025. This patient had extreme skeletal disease, hypoproteinemia and heavy proteinuria of at least three and one-half years' duration (9). Electrophoretic analysis of serum obtained before therapy, showed a normal pattern except for slight sharpness in the gamma boundary. Bence Jones proteinuria at this time averaged $18-20 \mathrm{gm}$. per day. Inulin and p-aminohippurate clearance studies on two occasions showed little or no impairment of renal function (28).

The urinary protein was studied electrophoretically on four occasions during a period of 20 months. Over $95 \%$ of the protein was represented by a homogeneous component with a mobility of 1.5 . When urinary protein was added to the serum, its electrophoretic mobility was the same as that of the abnormal gamma component.

Two diffusion studies of the urinary protein showed $\mathrm{D}_{20, \mathrm{w}}^{\infty}=9.1$ and 7.7. The latter value was determined under the more favorable technical circumstances. Three ultracentrifuge runs at protein concentrations of $0.73 \%$, $1.5 \%$, and $2.87 \%$ showed a single component, $\mathrm{S}_{20, \mathrm{w}}^{\infty}=$ $3.45,3.36$, and 3.35 , respectively. The molecular weight of the urinary protein was calculated at $37,100-42,000$ (Table I).

Case 11. J. F., C47338. This 72 year old lawyer had impaired health of three to four years' duration, extensive skeletal disease, and mild anemia (9). The NPN was not elevated but inulin and p-aminohippurate clearances showed severely impaired renal function (28). The serum protein concentration before therapy was increased to 13.0 gm. per $100 \mathrm{cc}$. of which $9.0 \mathrm{gm}$. were a gamma component, mobility 1.4. He excreted $1.6-2.2 \mathrm{gm}$. of protein in the urine per day of which $90 \%$ by electrophoretic analysis was a homogeneous component with a mobility of 2.7 (Table I). 


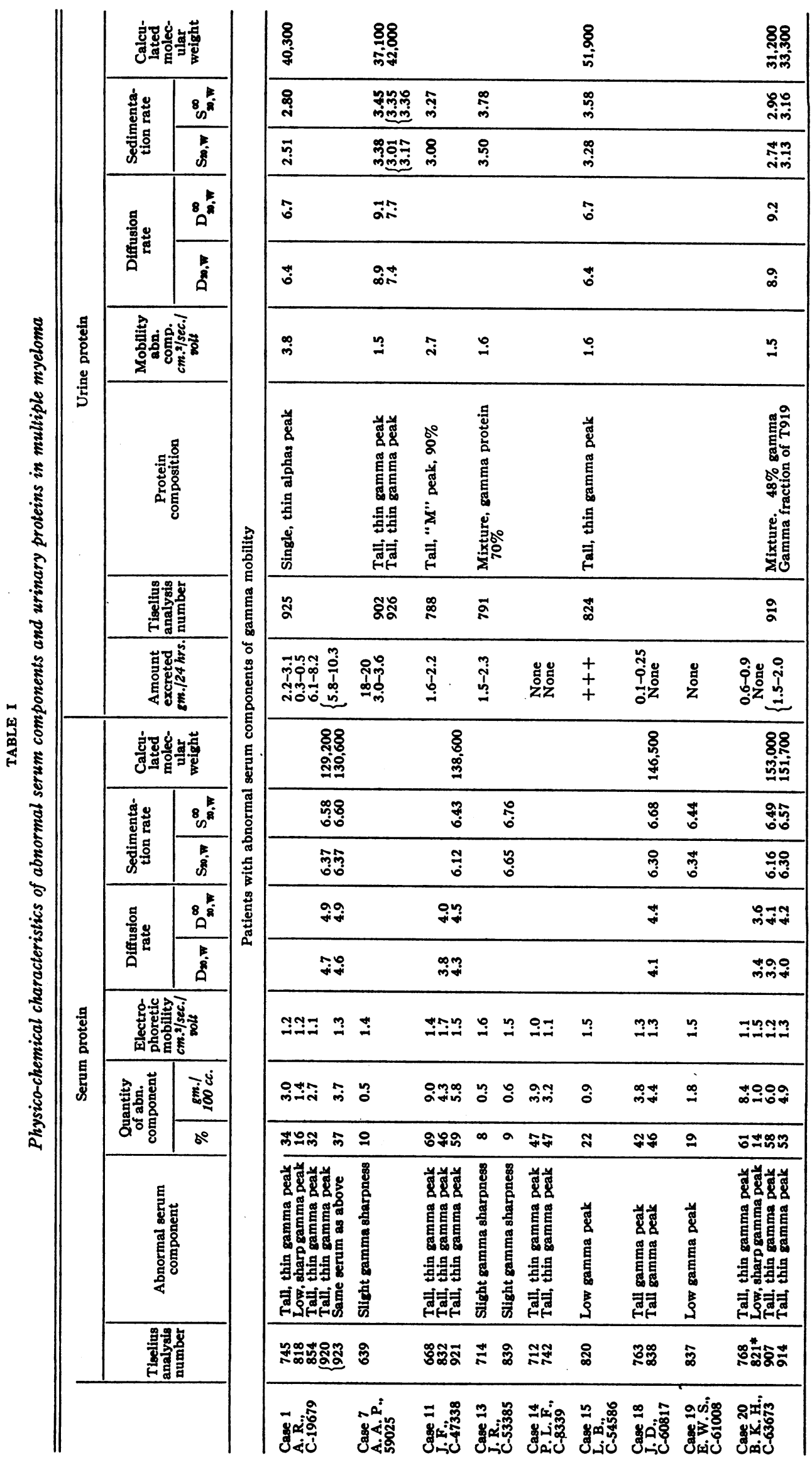




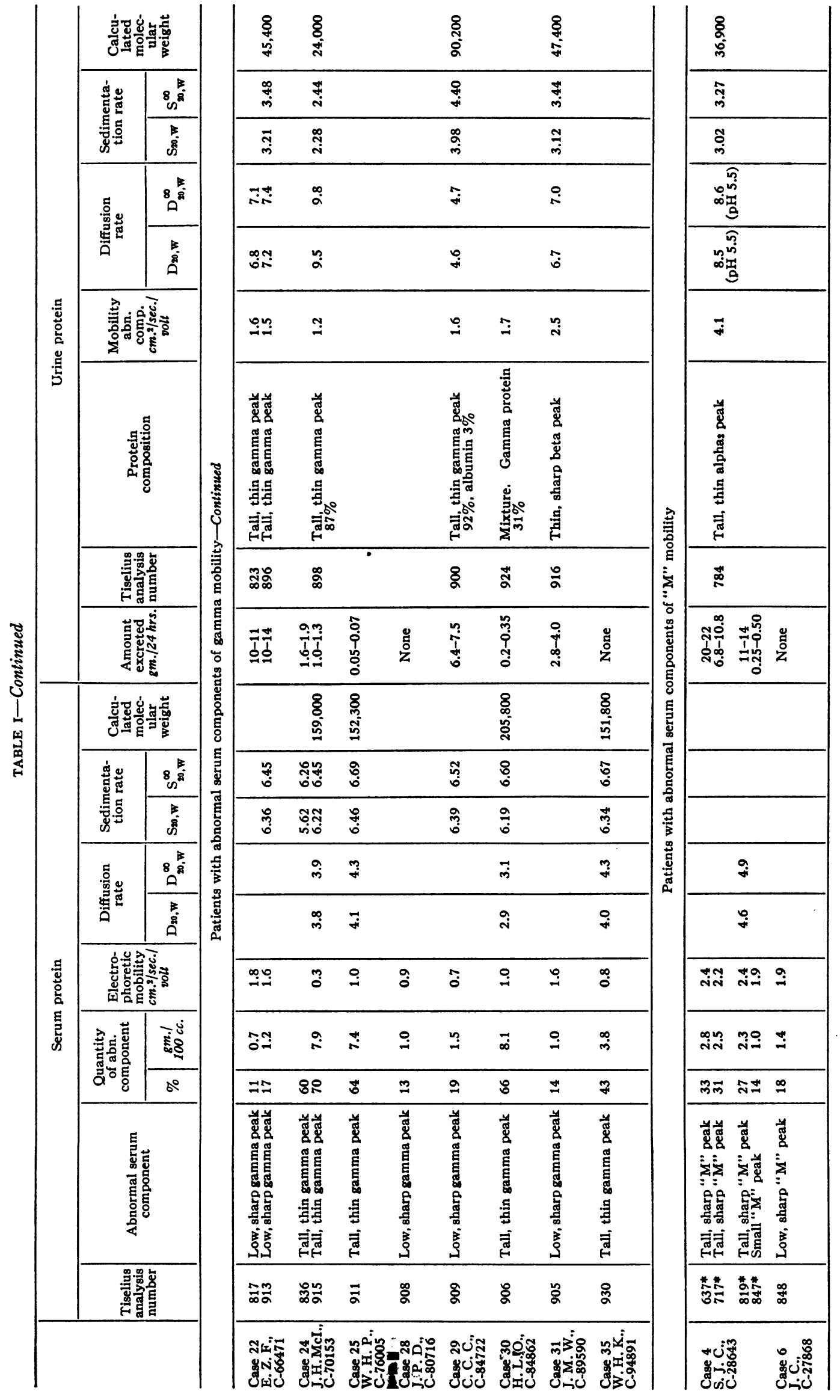




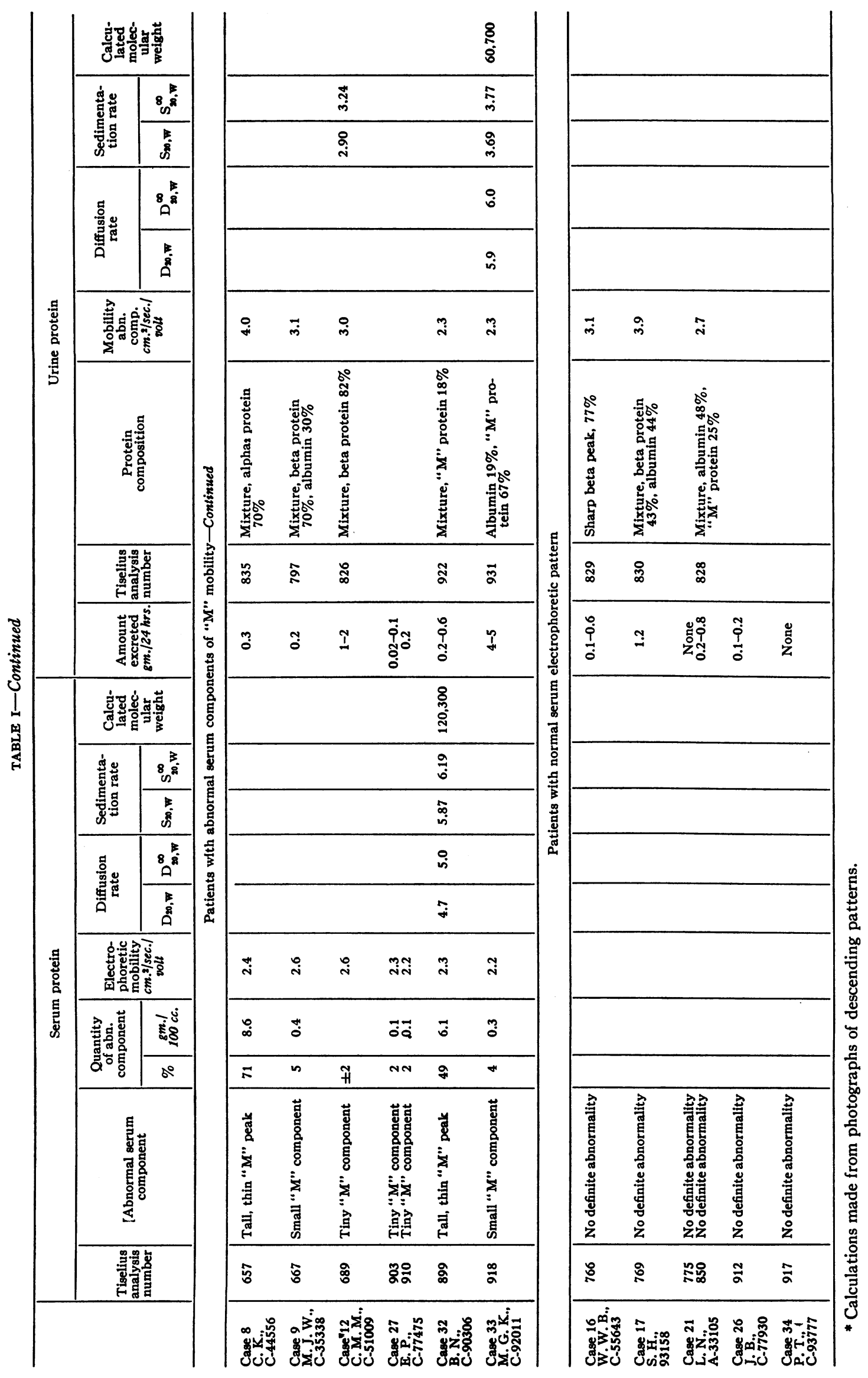


In the ultracentrifuge, gamma protein from the serum and the urine protein sedimented as homogeneous components, $S_{20, \mathrm{w}}^{\infty}=6.43$ and 3.27 , respectively. The molecular weight of the abnormal serum constituent was calculated at nearly 140,000 . The sedimentation rate of the urine protein was comparable to that of Bence Jones protein with a molecular weight of around 40,000 .

Case 13. J. R., C53385. This 57 year old housewife, admitted to Duke Hospital on February 3, 1949, had developed, in 1938, a large tumor in the frontal area of the skull that became smaller after irradiation. In 1944, when thoracic vertebrae collapsed, $x$-ray films showed generalized skeletal demineralization. Five years later she had radiologic evidence of extremely severe skeletal disease, moderately severe anemia, and overgrowth of abnormal plasma cells in the bone marrow. There was no nitrogen retention. Inulin and p-aminohippurate clearances showed severely impaired renal function (28).

Two electrophoretic studies of the serum, one before therapy and another six months later, showed as the only abnormality, slight sharpness in the gamma protein boundary. The gamma component from the second electrophoretic run was removed and studied in the ultracentrifuge. Only a single component was demonstrable, $S_{20, \mathrm{w}}^{\infty}=6.76$.

During her initial hospital stay she excreted 1.5-2.3 gm. of protein per day in the urine. Seventy $\%$ of the protein on electrophoretic analysis was a single component with a mobility of 1.6 (Figure 7). The protein mixture was studied in the ultracentrifuge at a concentration of 1.98 gm. per $100 \mathrm{cc}$. The major component sedimented with a sharp boundary, $\mathrm{S}_{20}^{\infty}, \mathrm{w}=3.78$.

Case 14. P. L. F., C8339. This patient, with a plasmacytoma of the scapula, had an abnormal gamma component in her serum in a concentration of 3.9-3.2 gm. per 100 cc. $(9,27)$. Proteinuria was never detected. Inulin and p-aminohippurate clearance studies showed moderate impairment of renal function (28).

Case 15. L. B., C54586. This 49 year old colored woman was admitted to the hospital with severe congestive failure, anasarca and hypoproteinemia. She died a few hours later (27). There was no nitrogen retention. Proteinuria was heavy but the quantity excreted per day was not determined.

An abnormal gamma component with a mobility of 1.5 was present in the serum in a concentration of $0.9 \mathrm{gm}$. per $100 \mathrm{cc}$. Almost all of the urinary protein on electrophoretic analysis was one homogeneous component. Its mobility was approximately that of the gamma increment in the serum. In the ultracentrifuge the urinary protein sedimented as one homogeneous component. From the diffusion and sedimentation measurements its molecular weight was calculated at nearly 52,000 .

Case 18. J. D., C60817. This 58 year old colored farmer with extensive skeletal disease and mild anemia had a serum protein concentration of over $9.0 \mathrm{gm}$. per 100 cc. with an abnormal gamma component of 3.8-4.4 gm. (9) per $100 \mathrm{cc}$. His urine contained little or no protein. Inulin and p-aminohippurate clearance studies showed moderate impairment of renal function (28).
The gamma protein separated from the serum electrophoretically sedimented in the ultracentrifuge as a single component. The molecular weight was calculated at 146,500 .

Case 19. E. W. S., C61008. This 42 year old physician developed, in a period of six months, several areas of myelomatous skeletal destruction. His serum contained an abnormal gamma component amounting to $1.8 \mathrm{gm}$. per $100 \mathrm{cc}$. $(9,27)$. Only minute traces of protein were present in the urine. Clearance studies showed normal renal function (28). Gamma protein, separated from the serum electrophoretically, sedimented in the ultracentrifuge as a single component, $\mathrm{S}_{20}^{\infty} \mathrm{w}=6.44$.

Case 20. B. K. H., C63673. This 28 year old student had been ill with fever and severe anemia for six months. Before therapy his serum contained $13.9 \mathrm{gm}$. of protein per $100 \mathrm{cc}$. of which $8.4 \mathrm{gm}$. were an abnormal gamma component. Proteinuria ranged from 0.6-0.9 gm. per day (9). During a remission of his disease that lasted for several months, the gamma component in the serum fell to $\mathbf{1 . 0}$ gm. per $100 \mathrm{cc}$., and the urine became free of protein. During a fatal exacerbation of the myeloma following meningitis he developed hypercalcemia but had no nitrogen retention. Gamma protein in the serum at this time rose to $6.0-4.9 \mathrm{gm}$. per $100 \mathrm{cc}$., and the proteinuria to $1.5-2.0$ gm. per day.

Gamma protein was separated from the serum electrophoretically on two occasions and studied in the ultracentrifuge in concentrations of $0.89 \%$ and $0.71 \%$. Only a single homogeneous component could be identified, $\mathrm{S}_{\mathbf{2 0} \text {, w }}^{\infty}$ $=6.49$ and 6.57. The molecular weight calculated from the diffusion and sedimentation values was about 152,000 .

Electrophoretic study of the urinary protein, excreted during the final episode, showed a mixture of which nearly half was a component with virtually the same mobility as that of the abnormal serum constituent (Table I and Figure 7).

The urinary protein mixture was studied in the ultracentrifuge at a concentration of $2.0 \mathrm{gm}$. per $100 \mathrm{cc}$. The $\mathrm{S}_{20, \mathrm{w}}^{\infty}$ of the major urinary component was 2.96 . The gamma component of the urinary protein, removed after electrophoresis, sedimented as a homogeneous component, $\mathrm{S}_{20, \mathrm{w}}^{\infty}=3.16$. The molecular weight was calculated at about 33,000 (Table I).

At necropsy there was round cell infiltration and some hemorrhage in all the tissues. Round cell infiltration and calcinosis were present in the kidneys but there were no outstanding glomerular or tubular lesions.

Case 22. E. Z. F., C66471. This 57 year old farmer, disabled with back pain for four months, was admitted to the hospital after two to three weeks of rapidly progressive weakness, nausea, vomiting and confusion (27). X-ray films of the skeleton showed demineralization with compression of the 2nd and 4th lumbar vertebrae. The hemoglobin was $8.1 \mathrm{gm}$. per $100 \mathrm{cc}$. Bone marrow aspirated from the sternum contained $70 \%$ abnormal plasma cells. The blood NPN was 55, serum calcium 13.3 and phosphorus $5.1 \mathrm{mg}$. per $100 \mathrm{cc}$. The serum protein concentration was $6.0 \mathrm{gm}$. per $100 \mathrm{cc}$. He was given $220 \mathrm{gm}$. of urethane in a period of two months with only slight benefit. 
He died five months after the diagnosis of multiple myeloma was made.

Two electrophoretic analyses of the serum showed an abnormal gamma component with a mobility of 1.8-1.6 present in a concentration of $0.7-1.2 \mathrm{gm}$. per $100 \mathrm{cc}$. (Table I). In the ultracentrifuge the gamma protein sedimented as one homogeneous component, $S_{20, \mathrm{w}}^{\infty}=6.45$. Bence Jones proteinuria at the time of the serum analyses ranged from 10-14 gm. per day. Electrophoretic analysis of the urinary protein showed that over $95 \%$ of it was a homogeneous component with virtually the same electrophoretic mobility as the abnormal serum increment. In the ultracentrifuge the urine protein sedimented as one component. From the diffusion and sedimentation rates the molecular

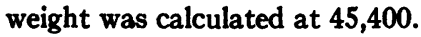

Case 24. J. H. McI., C70153. This 55 year old colored laborer had developed severe low back pain with sciatic radiation while lifting freight, two and one-half months before admission. Subsequently his left elbow became swollen and painful. His appetite failed and his weight fell from 147 to $101 \mathrm{lbs}$. During his last week at home he was confined to bed. Examination showed undernutrition, generalized skeletal tenderness, and a fusiform swelling of his left elbow with local heat, and limitation of movement.

A normochromic, normocytic anemia with hemoglobin reduced to $5.9 \mathrm{gm}$. per $100 \mathrm{cc}$. was present. The sternal bone marrow contained $80 \%$ abnormal plasma cells. $\mathrm{X}$-ray films of the skeleton showed severe generalized demineralization, without localized osteolytic lesions, and bony destruction about the left elbow with loss of joint space and irregularity of the articular surfaces. The NPN was 68, calcium 11.8 and phosphorus $5.5 \mathrm{mg}$. per $100 \mathrm{cc}$. The serum protein concentration varied from 10.8 to $14.0 \mathrm{gm}$. per $100 \mathrm{cc}$. The urine contained on an average $1.3 \mathrm{gm}$. of protein per day that gave the coagulation reactions of Bence Jones protein. A phenolsulfonphthalein test of renal function showed $20 \%$ of the dye excreted in one hour and $22 \%$ in two hours. Inulin and p-aminohippurate clearance studies showed a glomerular filtration rate of $32.2 \mathrm{cc}$. per minute, effective renal plasma flow of 309 cc. per minute, and maximal tubular excretion of p-aminohippurate $31 \mathrm{mg}$. per minute. The filtration fraction was 0.10 .

After three weeks of urethane therapy, the NPN and serum calcium values became normal, and the serum globulin concentration was reduced somewhat. After a few weeks he became free of pain, able to walk about and regained the use of his elbow. He remained moderately anemic, however. Four months after his hospital admission he died suddenly at home.

The electrophoretic pattern of his serum before therapy had a tall, sharp peak of very slow mobility, 0.3. When this component was separated from the serum electrophoretically and studied in the ultracentrifuge, it sedimented with a single sharp boundary, $S_{20,}^{\infty} w=6.26$ and 6.45. The molecular weight calculated from the diffusion and sedimentation rates was 159,000 . Electrophoretic study of the urinary protein showed that over $90 \%$ of it was a homogeneous component with a mobility of 1.2.
When studied in the ultracentrifuge at a concentration of $1.7 \mathrm{gm}$. per $100 \mathrm{cc}$., it sedimented with a sharp boundary, $\mathrm{S}_{20, \mathrm{w}}^{\infty}=2.44$. The calculated molecular weight was 24,000 .

Case 25. W. H. P., C76005. This 69 year old farmer had had severe weakness, anorexia, occasional nausea and vomiting, and pain about his trunk, spine and hips for four to six months. Examination on admission to the hospital showed him to be undernourished, chronically ill and uncomfortable due to skeletal pain. There was pronounced tenderness of all the superficial bones.

Blood studies showed a normochromic, normocytic anemia, with hemoglobin reduced to $9.0 \mathrm{gm}$., and a leucopenia of 2,500-2,000. Marrow aspirated from the sternum and iliac crest contained $10-20 \%$ abnormal plasma cells. $\mathrm{X}$-rays of his skeleton showed generalized demineralization and indefinite areas of osteolytic destruction. The NPN was 35 , serum calcium 11.6 , and phosphorus $2.8 \mathrm{mg}$. per $100 \mathrm{cc}$. The serum protein concentration was $10.2 \mathrm{gm}$. per $100 \mathrm{cc}$. The urine contained $0.05-0.07 \mathrm{gm}$. of protein per day that gave the qualitative reactions of Bence Jones protein. The phenolsulfonphthalein dye was excreted at a normal rate.

He was given $67 \mathrm{gm}$. of urethane during his 17 days in the hospital but then returned home, contrary to advice, and died three weeks later.

Electrophoretic study of the serum showed a large gamma component with a mobility of 1.0 present in a concentration of $7.4 \mathrm{gm}$. per $100 \mathrm{cc}$. The molecular weight calculated from diffusion and sedimentation measurements was about 152,000.

Case 28. J. P. D., C80716. This 29 year old business man developed pain about the right hip of sciatic radiation that gradually became more severe during a period of five months. X-ray films showed a large area of cystic demineralization in the right sacrum and ilium. Small osteolytic lesions were present in two ribs and in the center of the 5th lumbar vertebra. Biopsy of the ilium showed a plasmacytoma. He was given x-ray therapy to the pelvis and obtained partial relief of pain.

Physical examination two months later showed residual tenderness about the right iliac crest. There was no anemia. Bone marrow aspirated from the sternum was virtually normal. The NPN was 30 , calcium 9.3 , and phosphorus $2.9 \mathrm{mg}$. per $100 \mathrm{cc}$. The alkaline phosphatase was 2.8 Bodansky units per $100 \mathrm{cc}$. The serum protein concentration was $7.9 \mathrm{gm}$. per $100 \mathrm{cc}$. The excretion of phenolsulfonphthalein dye was normal. After he had taken $200 \mathrm{gm}$. of urethane by mouth during a period of two months, his pain subsided and he was able to work fulltime.

Electrophoretic analysis of the serum showed an abnormal gamma component, with a mobility of 0.9 , present in a concentration of $1.0 \mathrm{gm}$. per $100 \mathrm{cc}$. A second analysis 10 months later, after he had taken 1.0-1.5 gm. of urethane daily for six months, showed a reduction in the gamma component to $0.7 \mathrm{gm}$. per $100 \mathrm{cc}$. Protein was not found in the urine at any time.

Case 29. C. C. C., C84722. This 50 year old colored farmer complained of gradually increasing pain about his 
chest and spine for eight months and loss of 30 lbs. in weight. Three weeks before he was seen, his legs became numb and too weak for him to stand. Examination on admission to the hospital showed generalized bone tenderness, paralysis of the left leg, and impaired cutaneous and vibratory sensibilities up to the knee on the left and to the groin on the right.

Blood studies showed a normochromic, normocytic anemia with hemoglobin reduced to $7.6 \mathrm{gm}$. per $100 \mathrm{cc}$. The majority of the cells in marrow aspirated from the sternum were abnormal plasma cells. X-ray films of the skeleton showed osteolytic lesions in the ribs, scapulae, clavicles, humeri, skull, pelvis, proximal humeri and spine with collapse of $\mathrm{T} 5,8,10$, and 11 . The urine contained 6.4-7.5 gm. of Bence Jones protein per day. The NPN was elevated to $57-60 \mathrm{mg} . \%$. The serum calcium was $14.0 \mathrm{mg}$., phosphorus $4.0 \mathrm{mg}$., and alkaline phosphatase 3.0 Bodansky units per $100 \mathrm{cc}$. The serum protein concentration was $7.8 \mathrm{gm}$. per $100 \mathrm{cc}$.

After one month of urethane therapy he was free of pain at rest and able to begin moving about. The nitrogen retention and hypercalcemia disappeared. His anemia began to subside in six weeks time and the proteinuria fell to about one-third of the pretreatment level. The neurologic abnormalities disappeared. At five months he was able to walk one and one-half miles to town without discomfort or disability.

Electrophoretic analysis of the serum before treatment showed an abnormal component in the gamma protein, mobility 0.7, and concentration $1.5 \mathrm{gm}$. per $100 \mathrm{cc}$. (Figure 3, T909). Gamma protein, separated from the serum electrophoretically, sedimented in the ultracentrifuge with a single sharp boundary, $S_{2 a, w}^{\infty}=6.52$.

Electrophoretic study of the urinary protein showed that $92 \%$ was a homogeneous component of mobility 1.6 (Figure 3, T900). In the ultracentrifuge it sedimented as one component, $S_{20,}^{\infty} w=4.40$. Its molecular weight was calculated at about 90,000 .

The urinary protein was added to the serum and the electrophoresis repeated. The protein from the urine separated from the abnormal serum component and showed a mobility of 1.3 (Figure 3, T936).

Case 30. H. L. O., C84862. This 66 year old white male was admitted to Duke Hospital after eight to 12 months of increasingly severe back pain. On physical examination he had pronounced tenderness over the ribs, shoulders, spine and pelvis. X-ray films of the skeleton showed osteolytic lesions and demineralization of the ribs, clavicles, humeri and vertebrae, collapse of D10 and L5, and almost complete destruction of L4. Blood studies disclosed a normochromic, normocytic anemia with hemoglobin reduced to $9.6 \mathrm{gm}$. per $100 \mathrm{cc}$. Marrow aspirated from the sternum contained over $60 \%$ abnormal plasma cells. A small amount of protein was present in the urine, 0.2-0.35 gm. per day, that gave the coagulation reactions of Bence Jones protein. The NPN was $32 \mathrm{mg}$., calcium $10.2 \mathrm{mg}$., phosphorus $4.2 \mathrm{mg}$. and phosphatase 2.2 Bodansky units per $100 \mathrm{cc}$. The serum appeared viscous. Its protein content was increased to $12.1 \mathrm{gm}$. per $100 \mathrm{cc}$. The
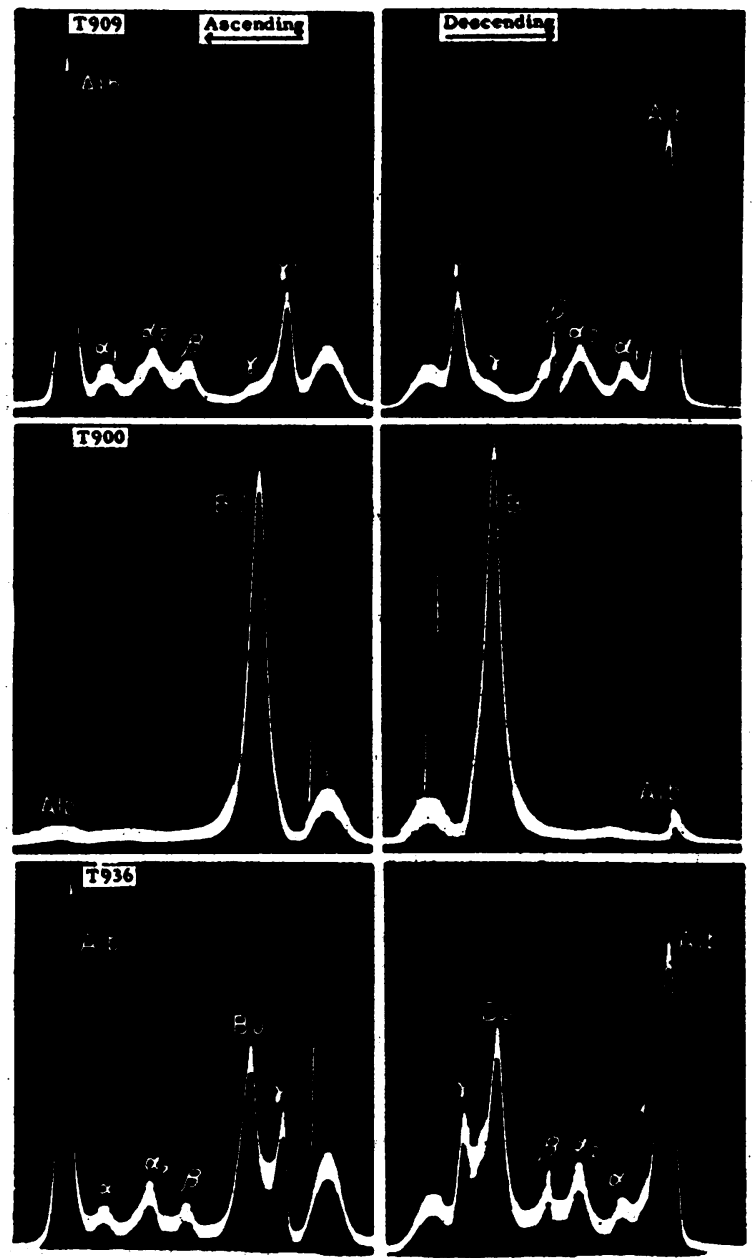

Fig. 3. Case 29, C. C. C., C84722. Photographs of Electrophoretic Patterns of Seruy and Urinary Proteins

T909, serum before treatment; T900, Bence Jones protein from urine; and T936, mixture of serum and urinary proteins.

thymol turbidity test was strongly positive, 30 units of turbidity and $4+$ flocculation.

He was given $120 \mathrm{gm}$. of urethane during a period of four weeks in the hospital but he steadily became worse. He was taken home and died two days later.

Electrophoretic analysis of the serum showed an extraordinarily large gamma increment, $8.1 \mathrm{gm}$. per $100 \mathrm{cc}$., with a mobility of 1.0. This component, when separated from the serum electrophoretically and studied in the ultracentrifuge, sedimented with one sharp boundary, $\mathbf{S}_{\mathbf{2 0}}^{\infty} \mathbf{w}=$ 6.60. Its molecular weight was calculated at somewhat over 200,000 .

Protein was recovered from a large volume of urine. On electrophoresis it was a mixture in which the largest component was gamma protein with a mobility of 1.7 .

Case 31. J. M. W., C89590. This 53 year old white 
farmer was admitted to the hospital for the investigation of a painful $8 \times 10 \mathrm{~cm}$. tumor of his left chest wall which had developed in a period of two months. Roentgen films showed partial destruction of the 9 th to 11 th ribs with surrounding soft tissue swelling, and a cystic area $4 \mathrm{~cm}$. in diameter in the body of the pubis on the right. Biopsy of the chest tumor showed it to be a plasmacytoma.

Study of the peripheral blood showed no anemia or cellular abnormality. Marrow aspirated from a tender area in the sternum contained $98 \%$ abnormal plasma cells. The blood NPN, serum calcium, phosphorus, and alkaline phosphatase determinations were normal. He excreted $2.8-4.0 \mathrm{gm}$. of Bence Jones protein in the urine per 24 hours.

Electrophoretic analysis of the serum showed an abnormal gamma component with a mobility of 1.6 present in a concentration of $1.0 \mathrm{gm}$. per $100 \mathrm{cc}$. Nearly $100 \%$ of the urinary protein on electrophoresis was a homogeneous component of mobility 2.5. It sedimented in the ultracentrifuge as one sharply bounded component. The molecular weight was calculated from diffusion and sedimentation measurements at about 47,000 .

Case 35. W. H. K., C 94891 . This 72 year old retired engineer requested examination regarding a tumor of the skull which had been enlarging for some three months. $\mathrm{X}$-ray films showed a large area of bony destruction under the tumor and numerous small osteolytic lesions, such as were present also in the ribs, vertebrae, and pelvis. Biopsy of the skull tumor showed it to be a plasmacytoma. The peripheral blood findings were normal. Marrow aspirated from the sternum contained $15 \%$ abnormal plasma cells. The blood NPN, serum calcium, phosphorus, and alkaline phosphatase determinations were normal. Many urinalyses showed no protein.

Electrophoretic study of the serum showed a large abnormal gamma component with a mobility of 0.8 present in a concentration of $3.8 \mathrm{gm}$. per $100 \mathrm{cc}$. When separated off electrophoretically and studied in the ultracentrifuge, it sedimented as one component. The molecular weight was calculated at nearly 152,000 .

Case 4. S. J. C., C28643. This patient's illness was studied for a period of over two years $(9,26)$. His serum contained an abnormal " $M$ " component with an electrophoretic mobility of 2.2-2.4. During his first relapse its concentration was $2.8 \mathrm{gm}$. per $100 \mathrm{cc}$. ('Table I). Bence Jones proteinuria ranged from 20-22 gm. per day. After urethane administration the serum component fell to 2.3-2.5 gm. per $100 \mathrm{cc}$. and the proteinuria about $50 \%$. Inulin and p-aminohippurate clearance studies at this time showed virtually normal renal function (28).

After urethane therapy had to be suspended late in the course of his illness, the abnormal serum component fell to $1.0 \mathrm{gm}$. per $100 \mathrm{cc}$. and the proteinuria to $0.25-0.5 \mathrm{gm}$. per day (9).

The urinary protein was studied by electrophoresis on two occasions. Over $90 \%$ of it was a single component with a mobility of 4.1 . When this protein was added to the serum a new boundary was produced, faster in mobility and well separated from the "M" component (Figure 4).

The diffusion rate of the abnormal component in the serum, $D_{20, w}^{\infty}=4.9$, was comparable to that of high molecular weight proteins in other patients (Table I). The urinary protein sedimented as one component in the ultracentrifuge. Its molecular weight was calculated at nearly 37,000 .

Case 6. J.C., C27868. This patient, whose illness began with spinal cord compression by a plasmacytoma, has been observed for more than three years (9). An abnormal component with a mobility of 1.9 was present in his serum in a concentration as high as $1.4 \mathrm{gm}$. per $100 \mathrm{cc}$. No protein was detected in the urine at any time. The renal clearance of infused inulin and p-aminohippurate one year after the onset of his disease was normal (28).

Case 8. C. K., C44556. This 40 year old colored male was admitted to the hospital after four to six months of increasingly severe back pain. On physical examination he was suffering from generalized bone pain, underweight, and acutely ill. A normochromic, normocytic anemia was present with hemoglobin reduced to $8.2 \mathrm{gm}$. per $100 \mathrm{cc}$. Marrow from different sites contained 25-90\% abnormal plasma cells. X-ray films of the skeleton showed demineralization and multiple osteolytic lesions in the skull, ribs, vertebrae, and proximal femurs. The NPN was 31 mg., calcium $15.0 \mathrm{mg}$, phosphorus $2.5 \mathrm{mg}$. and alkaline
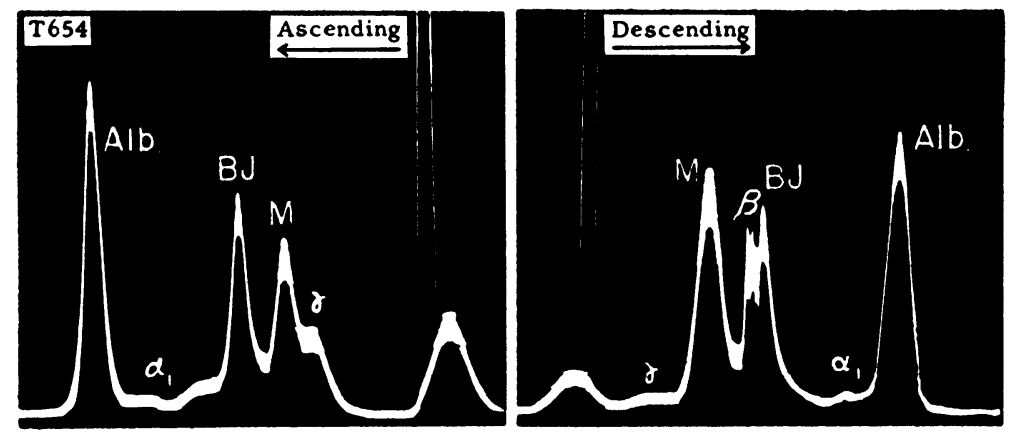

Fig. 4. Case 4, S. J. C., C28643. Photograph of Electrophoretic Pattern of Mixture of Bence Jones Protein and Serum For serum patterns alone see Figure $6(9)$. 
phosphatase 1.3 Bodansky units per $100 \mathrm{cc}$. The phenolsulfonphthalein dye was excreted at the rate of $16 \%$ in the first half hour and $8 \%$ in the second half hour. The specific gravity of the urine after maximal concentration was 1.012. Inulin and p-aminohippurate clearances showed seriously impaired renal function (28).

He died suddenly four weeks after admission. Autopsy showed widespread myeloma. There was precipitated protein in the renal tubules and degenerative changes in the tubular epithelium.

Electrophoretic study of the serum showed an abnormal component with a mobility of 2.4 present in a concentration of $8.6 \mathrm{gm}$. per $100 \mathrm{cc}$. The urine contained $0.3 \mathrm{gm}$. of protein per 24 hours which gave positive Bence Jones coagulation tests. Electrophoretic study of the urine protein showed a mixture of which $70 \%$ was a component with a mobility of 4.0 (Figure 7).

Case 9. M. J. W., C35338. This 53 year old woman with chronic back pain of six months' duration had roentgen evidence of severe skeletal demineralization but no anemia (27). The bone marrow contained $11 \%$ abnormal plasma cells. The urine contained up to $0.2 \mathrm{gm}$. protein per day. Inulin and p-aminohippurate clearance studies showed little impairment of renal function (28).

Electrophoretic study of the serum showed an extremely small " $M$ " component, mobility 2.6 , present in a concentration of $0.4 \mathrm{gm}$. per $100 \mathrm{cc}$. Electrophoretic study of the urinary protein showed a mixture, of which $70 \%$ was a globulin component with a mobility of 3.1 .

Case 12. C. M. M., C51009. This 77 year old farmer had been ill for five years before his hospital admission on December 29, 1948. His presenting complaints related to destruction of several cervical vertebrae (27). His hemoglobin was $12.8 \mathrm{gm}$. per $100 \mathrm{cc}$. The sternal bone marrow contained over $60 \%$ abnormal plasma cells. There was no nitrogen retention. The phenolsulfonphthalein dye was excreted poorly, $20 \%$ in the first hour and $10 \%$ in the second hour. Inulin and p-aminohippurate clearance studies showed severely impaired renal function (28).

Electrophoretic study of the serum showed the smallest recognizable abnormality, a tiny component with a mobility of 2.6 lying between the gamma and beta protein boundaries. The urine contained 1-2 $\mathrm{gm}$. of protein per 24 hours that gave Bence Jones coagulation reactions. Over $80 \%$ of the urinary protein on electrophoresis was represented by a globulin component with an average mobility of 3.0 (Figure 7). In the ultracentrifuge the urine protein sedimented as a single component, $\mathrm{S}_{20, \mathrm{w}}^{\infty}=$ 3.24.

Case 27. E. P., C77475. This 51 year old woman had gradually become incapacitated over a period of six to 10 months by low back pain. X-ray films showed pronounced demineralization of the skeleton with innumerable small osteolytic lesions in the ribs, scapulae, clavicles, humeri, vertebrae, pelvis and upper femurs. A chest $\mathrm{x}$-ray taken five years previously during an episode of penumonia showed, on review, definite osteolytic lesions in the ribs. Peripheral blood counts were normal. A bone marrow specimen contained $19 \%$ abnormal plasma cells. The blood NPN, serum calcium, phosphorus and alkaline phos-
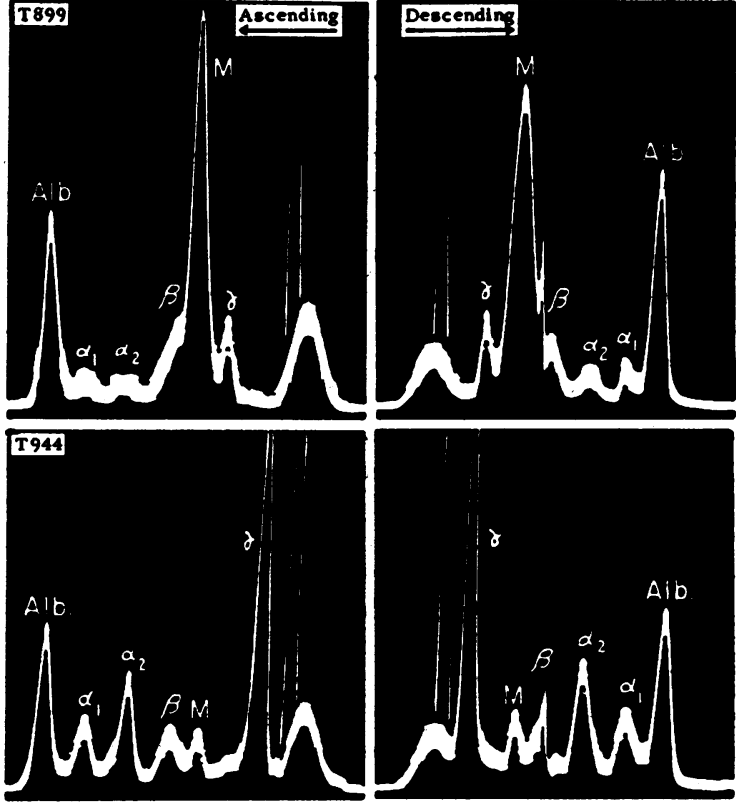

Fig. 5. Photographs of Electrophoretic Patterins of Sera of Patients with Multiple Myeloma Showing More Than One Abnormal Component

T899, Case 32, sharp gamma peak in addition to tall " $M$ " component; T944, Case 38, tall gamma increment and abnormal " $M$ " component.

phatase determinations and the excretion of phenolsulfonphthalein dye were normal. The urine contained up to $0.1-0.2 \mathrm{gm}$. of protein per 24 hours that gave the coagulation reactions of Bence Jones protein.

Electrophoretic study of the serum showed a tiny abnormal component with a mobility of 2.2.

Case 32. B. N., C90306. This 40 year old colored woman had had low back pain for $\mathbf{1 5}$ months severe enough to confine her to bed at home for eight months. On examination she was obese and comfortable in bed. There was slight tenderness over the spines of the lumbar vertebrae. X-ray films of her skeleton showed pronounced diffuse demineralization with flattening of the vertebral bodies. A normocytic, normochromic anemia with the hemoglobin reduced to $8.0 \mathrm{gm}$. per $100 \mathrm{cc}$. was present. Marrow aspirated from the sternum contained $95 \%$ abnormal plasma cells. The urine contained $0.2-0.6 \mathrm{gm}$. of protein per 24 hours but the coagulation reactions of Bence Jones protein could not be obtained. Phenolsulfonphthalein dye was excreted at a normal rate.

Electrophoretic analysis of the serum showed a large "M" protein component with a mobility of 2.3 present in a concentration of $6.1 \mathrm{gm}$. per $100 \mathrm{cc}$. A sharp peak was present in the adjacent gamma protein (Figure 5, T899). The serum was studied in the ultracentrifuge at a concentration of $0.91 \%$. In addition to the major component, which sedimented with a sharp boundary, there were two small heavier components and one lighter. The molecular weight of the major component was calculated at 120,000. 
Electrophoretic study of protein from the urine showed that half of it was albumin (Figure 7). A small globulin component, amounting to $18 \%$, had a mobility of 2.3 .

Case 33. M. G. K., C92011. This 49 year old white woman had been ill for 10 months with severe weakness, paraesthesias in the extremities and anemia treated symptomatically with blood transfusions. During this time she had lost $16 \mathrm{lbs}$. in weight. Eighteen years earlier she had been found to have tuberculosis. This was treated with pneumothorax initially, and three years later with thoracoplasty.

On physical examination she was thin, pale and chronically ill. Hematologic studies showed a normochromic, normocytic anemia with the hemoglobin reduced to $8.1 \mathrm{gm}$. per $100 \propto$. The white blood count ranged from 9,500 to over 18,000 , with a few immature myeloid cells present in the circulating blood. Bone marrow aspirated from different sites contained 10-38\% abnormal plasma cells. X-ray films of the skeleton showed demineralization and scattered irregular rarefactions in the ribs, scapulae, humeri, and proximal tibia and fibula. The blood NPN was $63 \mathrm{mg}$., calcium $11.2 \mathrm{mg}$. , phosphorus $2.8 \mathrm{mg}$. and alkaline phosphatase 5.3 Bodansky units per $100 \mathrm{cc}$. There was no detectable excretion of the phenolsulfonphthalein dye.

She became worse rapidly and died three weeks after admission to the hospital. Necropsy showed pulmonary tuberculosis with fibrosis about a cavity in which there were tubercle bacilli, amyloid deposits in small arteries, extensive hyalinization of the renal glomeruli, and protein casts and precipitated calcium in the tubules.

Electrophoretic study of the serum showed a very small " $M$ " component, mobility 2.2 , present in a concentration $0.3 \mathrm{gm}$. per $100 \mathrm{cc}$. The urine contained 4-5 gm. of protein per day of which $67 \%$ on electrophoretic analysis was a homogeneous component with a mobility of 2.3 (Figure 7).

Case 16. W. W. B., C55643. This 48 year old colored laborer, complaining of asthma, was found on routine urinalysis to excrete Bence Jones protein. Examination of the circulating blood showed normal values throughout. The sternal bone marrow contained $15 \%$ abnormal plasma cells. X-ray films of the skull, thorax, spine and pelvis showed no bony abnormality. The serum calcium, phosphorus and phosphatase determinations were normal. Inulin and $\mathrm{p}$-aminohippurate clearances showed no impairment of renal function (28).

The electrophoretic pattern of the serum showed no abnormal features. The urine protein amounted to 0.1$0.6 \mathrm{gm}$. per 24 hours. On electrophoresis over $77 \%$ of the urine protein was represented by a globulin component of mobility 3.1. There was no demonstrable albumin.

Case 17. S. H., 93158. This 54 year old colored woman was admitted to the hospital for the treatment of congestive heart failure which developed after some 12 years of arterial hypertension. Bence Jones protein was discovered on routine urinalysis.

Examination of the peripheral blood showed normal values. The bone marrow contained $24 \%$ huge abnormal plasma cells. The blood NPN was $34 \mathrm{mg}$., serum calcium $9.5 \mathrm{mg}$., phosphorus $2.8 \mathrm{mg}$., and alkaline phosphatase
3.5 Bodansky units per $100 \mathrm{cc}$. The serum protein concentration was $6.5 \mathrm{gm}$. per $100 \mathrm{cc}$. X-rays of the skull, thorax, spine and pelvis showed no bony abnormalities.

Electrophoretic study of the serum showed no definite abnormality. The urine contained about $1.2 \mathrm{gm}$. of protein per day. On electrophoretic analysis, $44 \%$ was albumin and $43 \%$ a component with a mobility of 3.9.

Case 21. L. N., A33105. This 46 year old white woman developed flaccid paralysis of the lower extremities due to collapse of the 6th thoracic vertebra with spinal cord compression (27). Laminectomy was performed and an extradural plasmacytoma partially resected. Examination of the peripheral blood subsequently showed normal values. Marrow. from the sternum contained $7 \%$ abnormal plasma cells. The blood NPN, serum calcium, phosphorus, and alkaline phosphatase determinations were all normal. The serum protein concentration was $7.2 \mathrm{gm}$. per $100 \mathrm{cc}$. Inulin and p-aminohippurate clearances showed moderate impairment of renal function (28).

During her convalescence in the hospital there was no protein in the urine. A few weeks later, when she was again active, proteinuria was consistently present in a concentration of $0.2-0.8 \mathrm{gm}$. per 24 hours. Electrophoretic study of the serum on two occasions showed no abnormality. Electrophoretic analysis of the urinary protein showed $48 \%$ albumin and $25 \%$ a homogeneous globulin component of mobility 2.7.

Case 26. J. B., C77930. This 65 year old colored laborer was admitted to the hospital complaining of back pain of 18 months' duration which had been severe enough to keep him from working for $\mathbf{1 0}$ months. A tumor of the sternum had been increasing in size for three months and for two to three weeks he had had severe generalized skeletal pain. Physical examination showed a weak, chronically ill, undernourished male with tenderness of the superficial bones who held himself immobile for fear of producing pain. There were nodular deformities over his ribs and sternum. X-ray films of the skeleton showed multiple osteolytic lesions in the skull, ribs, scapulae, clavicles, vertebrae and proximal femora.

Hematologic study showed no anemia but there was a small percentage of immature granulocytes and plasma cells in the circulating blood. Bone marrow from the sternum contained $68 \%$ abnormal plasma cells. The urine contained $0.1-0.2 \mathrm{gm}$. of protein per 24 hours that gave the coagulation tests of Bence Jones protein. The NPN on different determinations was 60-72 mg., serum calcium $17.0-17.5 \mathrm{mg}$. and serum protein concentration 6.7-7.6 gm. per $100 \mathrm{cc}$. The serum phosphorus was 4.1 mg. and the alkaline phosphatase 6.2 Bodansky units per $100 \mathrm{cc}$.

He responded well to urethane therapy. In a few weeks bone tenderness subsided and he had no pain at rest. The nitrogen retention disappeared. He became ambulatory but, seven months after the diagnosis was first made, relapsed and died.

Electrophoretic analysis of the serum before therapy showed no definite abnormality.

Case 34. P. T., C93777. This 58 year old colored laborer had a slight fall and fractured his left femur above 
the knee. The fracture site stabilized after being in a cast for two months, but with resumption of activity it broke again. On physical examination he was chronically ill and undernourished. There was a fusiform swelling of the left leg above the knee. X-ray films showed that the fracture passed through a cystic area of bone dissolution about which there was extensive callous formation. In the shaft of the femur above the fracture there were multiple osteolytic lesions. Other large and small destructive lesions were present in the pelvis, vertebrae, ribs and skull. The NPN was $35 \mathrm{mg}$., serum calcium $15.0 \mathrm{mg}$., phosphorus $2.3 \mathrm{mg}$., and phosphatase 7.9 Bodansky units per $100 \mathrm{cc}$. The serum protein concentration was $6.7 \mathrm{gm}$. per $100 \mathrm{cc}$.

The electrophoretic pattern of the serum was normal. The urine contained no protein at any time.

To summarize the findings regarding protein abnormalities in this group of patients with multiple myeloma, abnormal serum components were recognizable in the electrophoretic patterns of 25 of the 30 individuals. In 17 instances the abnormal component migrated as gamma protein, with an electrophoretic mobility of 0.3-1.7, and in eight between gamma and beta protein, with a mobility of 1.9-2.6.

While many sera showed minor and probably non-specific abnormalities in electrophoretic pattern, increase in alpha globulins, irregular variations in beta-lipoproteins, etc., the essential abnormality associated with the proliferation of abnormal plasma cells appeared to be the presence of an unusually homogeneous globulin constituent in the serum. The sera of two patients contained two clearly abnormal constituents each. In Case 32, in addition to a large " $M$ " component, there was a sharp peak in the gamma boundary (Figure 5, T899). In Case 38, a very large gamma component was present and a small " $M$ " component as well (Figure 5, T944).

The quantity of abnormal protein in the serum ranged from the smallest amounts demonstrable by electrophoresis, $0.1-0.5 \mathrm{gm}$. per $100 \mathrm{cc}$., to increments as large as $6-9 \mathrm{gm}$. per $100 \mathrm{cc}$. Some individuals with little abnormal protein in the serum excreted as much as 10-20 $\mathrm{gm}$. of Bence Jones protein in the urine daily. Others with large amounts excreted negligible amounts or none. In patients with the largest serum increments, however, proteinuria did not exceed 1-2 gm. per day. In individual patients with Bence Jones proteinuria and measurable amounts of abnormal protein in the serum, the amount of protein excreted in the urine remained roughly proportional to the concentration of abnormal protein in the serum as the disease activity was suppressed by therapy and as relapses occurred. Protein was not demonstrated in the urine of five patients at any time. In four of these the amount of abnormal protein in the serum was considerable, 1.0-3.9 gm. per $100 \mathrm{cc}$. Two patients with disease of widespread anatomic extent had no demonstrable abnormality in the electrophoretic pattern of their sera and minimal or no proteinuria.

In 17 individuals the electrophoretic mobility of the abnormal serum increment could be compared with that of the Bence Jones urinary protein they excreted. In nine instances the mobilities were virtually the same. In five patients the mobility of the urinary protein was somewhat greater than that of the component in the serum, and in three others it was much greater.

That the latter differences in electrophoretic mobility were significant, considering the effect of different media and the presence of other proteins $(29,30)$, was demonstrated by mixing serum and urinary proteins. In Case 7 the mobility of the abnormal serum and urinary components was virtually the same, 1.4 and 1.5 . Protein from the urine was added to the serum and on electrophoresis both components moved together. In Cases 1, 29, and 4, the mobility of the protein from the urine was more rapid than that of the abnormal component in the serum. After Bence Jones protein was added to the sera, the two abnormal components separated clearly on electrophoresis, the urinary protein retaining a faster mobility (Figures 1,3 and 4). Finally, Bence Jones proteins of different mobilities, from different patients, were mixed together and subjected to electrophoresis. Urinary proteins from Cases 1, 7 and 29 had calculated mobilities of $3.8,1.5$, and 1.6, respectively. Approximately equal quantities of these proteins were mixed together. On electrophoresis, the two of slower mobility moved as one component, and did not separate after twice the usual time allowed for migration, in spite of the great difference in molecular weight (Table I), but separated sharply from that of faster mobility (Figure 6 , T937). A mixture of approximately equal amounts of Bence Jones protein from Cases 1, 


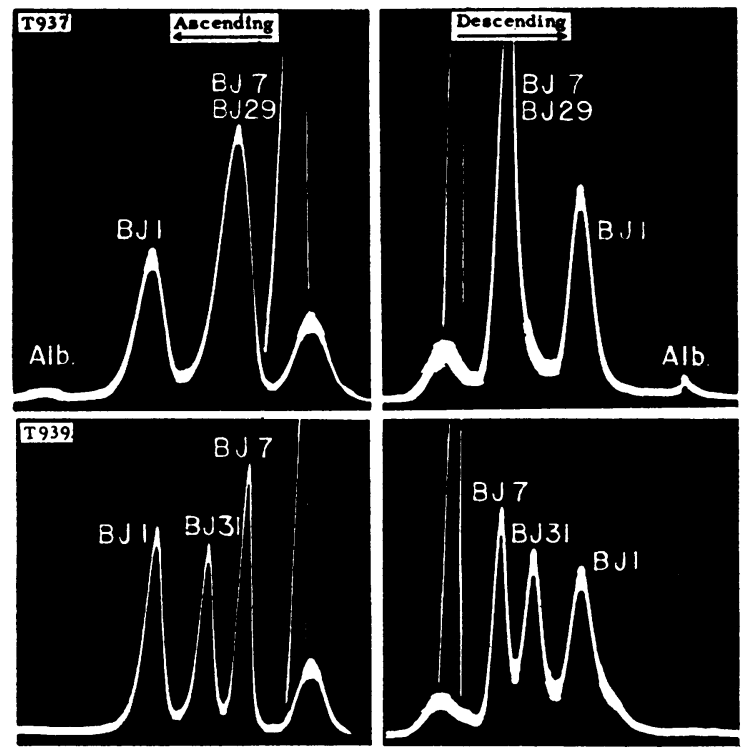

Fig. 6. Photographs of Electrophoretic Patterns of Mixtures of Bence Jones Urinary Proteins with the Same and Different Mobilities

T937, protein from Cases 1, 7 and 29; T939, protein from Cases 1,7 and 31 .

7 , and 31 , the latter having a mobility of 2.5 , was subjected to electrophoresis. Each of the three proteins separated sharply (Figure 6, T939).

Although Schlieren methods for measuring diffusion are of somewhat limited accuracy, the $\mathrm{D}_{20, \mathrm{w}}^{\infty}$ of abnormal gamma components present in high concentration in the sera of eight patients ranged from 3.1-5.0, with an average of 4.2. In two sera with " $M$ " increments, $D_{20, w}^{\infty}=$ 4.9 and 5.0. The diffusion rate of human serum albumin under the same conditions was $6.8 \pm$ 0.4 .

Abnormal gamma components separated from the sera of 13 patients were studied in the ultracentrifuge on 16 occasions. Normal gamma globulin was presumably present in many of these fractions but there was no differentiation in the ultracentrifuge. The sedimentation velocities were relatively uniform, $\mathrm{S}_{20, \mathrm{w}}^{\infty}=6.19$ to 6.76 with an average of 6.46 . The majority of the molecular weights calculated from the diffusion and sedimentation measurements were from 140,000 to 160,000 . One gamma component appeared to have a molecular weight of 130,000 and another over 200,000. The molecular weight of an " $M$ " component was calculated at 120,000 .

The diffusion rates of Bence Jones urinary proteins varied considerably, $D_{20, \mathrm{w}}^{\infty}=4.7$ to 9.8. The sedimentation velocity in the ultracentrifuge varied likewise, $S_{20, \mathrm{w}}^{\infty}=2.44$ to 4.40 . The calculated molecular weight of the Bence Jones proteins excreted by 10 patients was 24,000 (one patient), 32,000-42,000 (four patients), 45,000-52,000 (three patients), 60,000 (one patient), and 90,000 (one patient). In two additional instances, the sedimentation rate would suggest a molecular weight in the range of $32,000-42,000$ and in one other about 60,000 .

Considering the data relating to renal disease, five of the 30 patients had nitrogen retention before therapy. Three responded well to urethane, and in a few weeks the blood NPN became normal. Inulin and p-aminohippurate clearance studies, carried out in 15 patients, and tests of total kidney function showed severely impaired function in four who did not have azotemia. A correlation between the degree of

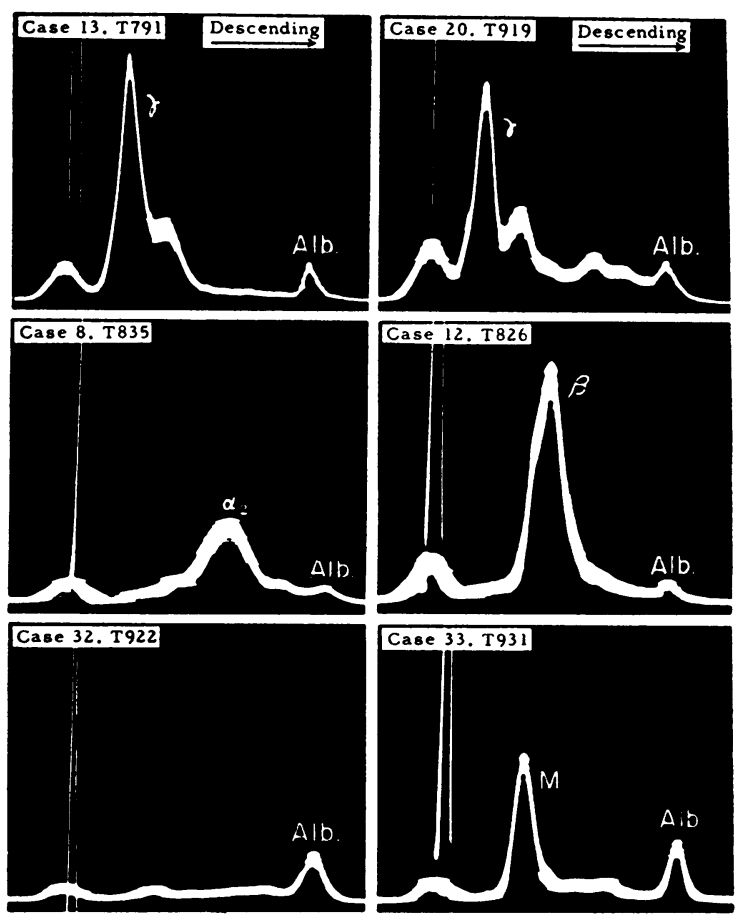

Fig. 7. Photographs of Electrophoretic Patterns Showing Mixtures of Protein in the Urine of Patients Who, with the Exception of Case 32, had Evidence of Renal Function Impairment 
renal functional impairment and 1 ) the amount of abnormal protein in the serum, or 2) the amount of Bence Jones protein excreted in the urine, its electrophoretic mobility, or its molecular weight, was not apparent. Impaired renal function occurred in patients whose urinary protein was almost exclusively Bence Jones type, but in Case 7 about 15-20 gm. of this protein had been excreted in the urine each day for nearly four years yet the renal clearances remained normal. Nitrogen retention developed in Case 26 before treatment was started. The electrophoretic pattern of his serum was not abnormal, and proteinuria did not exceed 0.1$0.2 \mathrm{gm}$. per day. Renal clearances were moderately impaired in Cases 14 and 18 in whom proteinuria was never detected. Patients with the greatest impairment of renal function were generally the sicker ones, and their urine contained a mixture of proteins, including albumin, in addition to the Bence Jones protein (Figure 7).

Eleven of the gamma components which had been separated electrophoretically from the sera were tested for precipitation at a $\mathrm{pH}$ of about 5.5 when heated to $59^{\circ} \mathrm{C}$. and for solubility at $100^{\circ}$ C. when acidified further with acetic acid and nitric acid. Gamma protein from three sera showed slight precipitation at the low temperature, but none dissolved well at boiling. All of the Bence Jones urinary proteins, with one exception, showed heavy precipitation below $59^{\circ} \mathrm{C}$. when tested similarly. Slightly over half of them dissolved well at $100^{\circ} \mathrm{C}$.

\section{DISCUSSION}

The results of the above studies are in general agreement with early investigations of the physico-chemical properties of the abnormal proteins in multiple myeloma, thoroughly reviewed in 1948 by Gutman (12). The serum increments vary in amount from those too small to appear in electrophoretic patterns of whole serum, up to 7-9 $\mathrm{gm}$. or more per $100 \mathrm{cc}$. They range in electrophoretic mobility from slower than the average for gamma protein to at least as fast as that of beta. The abnormal serum proteins produced by different individuals with the disease thus vary in their net surface charge. The components of slow mobility have a molecu- lar weight comparable to that of normal gamma globulin. Those of more rapid mobility, studied in a few instances, may be of smaller molecular size.

Although the molecular weight of Bence Jones urinary protein is generally given as 35,000 40,000 , one of the first three specimens studied had a value of about 70,000 (24). Subsequent measurements of sedimentation and diffusion rates have indicated a considerable variation in the size of the protein molecule in different cases $(5,31,32)$. The molecular weight of the Bence Jones proteins excreted by our patients, usually between 30,000 and 60,000 with extremes of 24,000 and 90,000 , is probably indicative of the extent of the variation in a representative group of individuals with this disease.

The extent to which the abnormal serum constituents in multiple myeloma represent Bence Jones proteinemia was investigated by Gutman and collaborators $(4,5,12)$. It appeared that only a very small proportion of the serum increments, in many if not the majority of cases, was due to this protein. By adding Bence Jones protein to sera they were able to augment or introduce serum constituents of beta mobility or intermediate between beta and gamma. The electrophoretic mobility of their Bence Jones proteins ranged from 1.4 to 3.1 , generally faster than that of the abnormal serum component in the same patient. They did not regard the differences between the mobility of the serum increments and that of the Bence Jones protein excreted as significant. In their Case 11, a large serum component with a mobility between beta and gamma protein sedimented in the ultracentrifuge at $4.0 \mathrm{~S}$., as compared to that of the Bence Jones protein sedimentation rate of 2.8 . Their Case 41 did not have Bence Jones protein in the urine on repeated examinations, but had a large beta increment in the serum. When prepared for study in the ultracentrifuge, the sedimentation rate of the major serum component was slow, 3.0. On dilution of the serum a protein not completely precipitable by trichloroacetic acid appeared. The findings suggested that the serum increment in this instance was a protein complex dissociable on dilution.

Our observations regarding the electrophoretic behavior of the abnormal serum and urinary 
proteins, separately and in mixtures, indicate that the Bence Jones protein excreted by a given patient has either the same, or a significantly greater, electrophoretic mobility than the anomalous serum constituent. If the serum and urinary proteins from a given patient had the same mobility, the electrophoretic pattern of the serum would give no information, of course, as to the possibility of Bence Jones proteinemia. If the mobilities were appreciably different, as occurred in nearly half of our cases, a significant quantity of Bence Jones protein in the serum should produce a second abnormal constituent of faster mobility. These were not found.

The suggestion was made long ago that molecular size is important in determining whether or not abnormal proteins are retained in the serum or are excreted in the urine (2). Bence Jones proteins fall within the range of those readily filterable through the glomeruli $(17,18)$. They may be found in the urine with or without albumin, which has a molecular weight of about 70,000 (33). It is of interest that in our Case 29, a Bence Jones protein with a molecular weight estimated at 90,000 was present in the urine in a concentration 30 times that of albumin. Protein increments retained in the serum appear to have a molecular weight of 120,000 or more $(2,3,5,12,31,34-36)$.

The relation of the abnormal serum components in multiple myeloma to Bence Jones urinary protein can be explained by a simple hypothesis consistent with our existing information. The proliferating plasma cells apparently produce a protein of abnormal homogeneity and of high molecular weight. Bence Jones proteins are abnormally homogeneous also, and their molecular weight is one-third to one-sixth that of the serum increments. As plasma cell growth in multiple myeloma is suppressed by urethane, and the concentration of abnormal protein in the serum is reduced, the quantity of Bence Jones protein excreted in the urine decreases or may virtually disappear. The opposite changes occur during relapse. Although the plasma cells could conceivably synthesize more than one variety of protein simultaneously, it seems more plausible that Bence Jones proteins are derived from the serum increments, as a fraction of the larger molecules filterable through the glomeruli. The faster electrophoretic mobility of some of the urinary proteins would indicate an increase in surface charge coming about during the process of fragmentation. Where and how his occurs is a matter for further study. Multiple abnormal serum components, as illustrated in Figure 5, might result from the accumulation in the serum of protein molecules of different mobility, still too large to be readily excreted into the urine. The great variation in the amount of abnormal protein demonstrable in the serum, or present in the urine, in individual patients indicates a considerable difference in either the rate these proteins are synthesized, or in the rate they are broken down. Fragmentary knowledge suggests a rapid synthesis and short survival $(37,38)$.

The central phenomenon in multiple myeloma is abnormal plasma cell proliferation. In a high percentage of cases, but not invariably, this is accompanied by the appearance of abnormal proteins in the serum and/or urine. The type of protein abnormality varies from patient to patient but remains qualitatively constant once it has developed $(4,9)$. The outstanding property so far recognized that differentiates normal from abnormal proteins in this disease is the remarkable homogeneity of the latter (39).

Regarding the renal complication of myeloma, it appears to be reversible in some instances, and ordinarily non-progressive in those who respond well to therapy. It appears to occur in patients who are severely ill with the disease, rather than as a result of the excretion of abnormal protein (28).

\section{CONCLUSIONS}

1) The abnormal serum and urinary proteins in 30 patients with multiple myeloma were studied, many during different stages of disease activity, by methods including electrophoresis and ultracentrifugation.

2) Abnormal serum components, recognizable in the electrophoretic patterns of 25 of the 30 patients, varied from minute increments to as much as 7-9 gm. per $100 \mathrm{cc}$.

3) The electrophoretic mobility of the serum increments, 0.3-2.6, ranged from slower than that of gamma to that of beta protein, while the electrophoretic mobility of Bence Jones proteins, 
1.2-4.1, ranged from that of gamma to alpha, globulin.

4) A comparison of the electrophoretic mobility of the abnormal serum increments in 17 patients with that of the Bence Jones urinary protein they excreted, showed virtually the same mobility in nine instances, and a more rapid mobility for the Bence Jones protein in eight instances. Electrophoretic study of mixtures of urinary protein and serum showed that these differences in mobility were significant.

5) Although the concentration of abnormal protein in the serum remained proportional to the amount of Bence Jones protein excreted in the urine in individual patients during fluctuations in disease activity, some patients had large quantities of abnormal protein in the serum, and little or no proteinuria, and vice versa.

6) Abnormal serum components had diffusion rates of $\mathrm{D}_{20, \mathrm{w}}^{\infty}=3.1-5.0$ (in 10 patients) and sedimentation velocities of $\mathrm{S}_{20, \mathrm{w}}^{\infty}=6.17-6.76$ (in 14 patients). Calculated molecular weights ranged from 120,000 to 200,000 with the majority between 140,000 and 160,000.

7) Bence Jones urinary proteins varied in diffusion rate, $D_{20}^{\infty}, w=4.7-9.8$, and sedimentation rate, $S_{20, \mathrm{w}}^{\infty}=2.44-4.40$. The calculated molecular weight of Bence Jones proteins excreted by 10 patients was 24,000 ( 1 patient), $32,000-42,000$ (4 patients), 45,000-52,000 (3 patients), 60,000 (1 patient), and 90,000 (1 patient).

8) Available information is compatible with the hypothesis that the small sized Bence Jones urinary proteins may be derived from the serum increments of high molecular weight.

\section{ACKNOWLEDGMENTS}

We are greatly indebted to Drs. J. W. Beard and D. Gordon Sharpe for the use of electrophoretic facilities, to Dr. George W. Schwert for advice and assistance with ultracentrifuge analysis, and to Mrs. Nancy Brewer and Miss Betty Simpson for technical assistance.

\section{REFERENCES}

1. Kydd, D. M., Bence-Jones protein in serum. J. Biol. Chem., 1934, 107, 747.

2. von Bonsdorff, B., Groth, H., and Packalén, T., On the presence of a high-molecular crystallizable protein in blood serum in myeloma. Folia haemat., 1938, 59, 184.
3. Kekwick, R. A., The serum proteins in multiple myelomatosis. Biochem. J., 1940, 34, 1248.

4. Gutman, A. B., Moore, D. H., Gutman, E. B., McClellan, V., and Kabat, E. A., Fractionation of serum proteins in hyperproteinemia, with special reference to multiple myeloma. J. Clin. Invest., 1941, 20, 765.

5. Moore, D. H., Kabat, E. A., and Gutman, A. B., Bence-Jones proteinemia in multiple myeloma. J. Clin. Invest., 1943, 22, 67.

6. Bayrd, E. D., and Heck, F. J., Multiple myeloma; a review of 83 proved cases. J.A.M.A., 1947, 133, 147.

7. Lumb, G., Solitary plasmacytoma of bone with renal changes. Brit. J. Surg., 1948, 36, 16.

8. Adams, W. S., Alling, E. L., and Lawrence, J. S., Multiple myeloma. Its clinical and laboratory diagnosis with emphasis on electrophoretic abnormalities. Am. J. Med., 1949, 6, 141.

9. Rundles, R. W., Dillon, M. L., and Dillon, E. S., Multiple myeloma. III. Effect of urethane therapy on plasma cell growth, abnormal serum protein components and Bence Jones proteinuria. J. Clin. Invest., 1950, 29, 1243.

10. Hektoen, L., and Welker, W. H., Immunological differences of crystalline Bence-Jones proteins. Biochem. J., 1940, 34, 487.

11. Wuhrmann, F. H., Wunderly, C., and Hăssig, A., Immunological investigations in ten cases of plasmacytoma. Brit. J. Exper. Path., 1950, 31, 507.

12. Gutman, A. B., The plasma proteins in disease, in Advances in Protein Chemistry, Vol. IV, edited by Anson, M. L.; and Edsall, J. T. Academic Press, Inc., New York, 1948.

13. Martin, N. H., A study of the plasma and tissue globulins in myelomatosis. J. Clin. Invest., 1947, 26, 1189.

14. Bing, J., Further investigations of hyperglobulinemia. I and II. Acta med. Scandinav., 1940, 103, 547 and 565.

15. Bing, J., Fagraeus, A., and Thorell, B., Studies on nucleic acid metabolism in plasma cells. Acta physiol. Scandinav., 1945, 10, 282.

16. Barr, D. P., The function of the plasma cells. Am. J. Med., 1950, 9, 277.

17. Kerridge, P. M. T., and Bayliss, L. E., The physiology of proteinuria and its clinical significance. Lancet, 1932, 2, 785.

18. Bott, P. A., and Richards, A. N., The passage of protein molecules through the glomerular membranes. J. Biol. Chem., 1941, 141, 291.

19. Cooper, G. R., Craig, H. W., and Beard, J. W., Electrophoretic analysis of syphilitic, biologic false positive, and normal human sera. Am. J. Syph., Gonor. \& Ven. Dis., 1946, 30, 555.

20. Neurath, H., The investigation of proteins by diffusion measurements. Chem. Rev., 1942, 30, 357.

21. Neurath, H., Cooper, G. R., and Erickson, J. O., The shape of protein molecules. II. Viscosity and 
diffusion studies of native proteins. J. Biol. Chem., 1941, 138, 411.

22. Gosting, L. J., and Morris, M. S., Diffusion studies on dilute aqueous sucrose solutions at 1 and $25^{\circ}$ with the Gouy interference method. J. Am. Chem. Soc., 1949, 71, 1998.

23. Schwert, G. W., The molecular size and shape of the pancreatic proteases. I. Sedimentation studies on chymotrypsinogen and on $\alpha$ - and $\gamma$-chymotrypsin. J. Biol. Chem., 1949, 179, 655.

24. Svedberg, T., and Pedersen, K. O., The Ultracentrifuge. Clarendon Press, Oxford, 1940.

25. Lauffer, M. A., The influence of concentration upon the sedimentation rate of tobacco mosaic virus. J. Am. Chem. Soc., 1944, 66, 1195.

26. Loge, J. P., and Rundles, R. W., Urethane (ethyl carbamate) therapy in multiple myeloma. Blood, 1949, 4, 201.

27. Rundles, R. W., and Reeves, R. J., Multiple myeloma. II. Variability of roentgen appearance and effect of urethane therapy on skeletal disease. Am. J. Roentgenol. \& Radium Ther., 1950, 64, 799.

28. Armstrong, J. B., A study of renal function in patients with multiple myeloma. Am. J. M. Sc., 1950, 219, 488.

29. Longsworth, L. G., and MacInnis, D. A., The interpretation of simple electrophoretic patterns. J. Am. Chem. Soc., 1940, 62, 705.

30. Luetscher, J. A., Jr., Electrophoretic analysis of plasma and urinary proteins. J. Clin. Invest., 1940, 19, 313 .
31. McFarlane, A. S., The behavior of pathological sera in the ultracentrifuge. Biochem. J., 1935, 29, 1175. The behavior of urinary proteins in the ultracentrifuge. Ibid., 1202.

32. Udin, B., and Putnam, F. W., Investigation of BenceJones proteins. Federation Proc., 1951, 10, 262.

33. Pedersen, K. O., Ultracentrifugal Studies on Serum and Serum Fractions. Almqvist \& Wiksells, Uppsala, 1945.

34. Holmberg, C. G., and Grönwall, A., Ein neues krystallinisches Serumglobulin. Ztschr. f. physiol. Chem., 1942, 273, 199.

35. Shapiro, S., Ross, V., and Moore, D. H., A viscous protein obtained in large amount from the serum of a patient with multiple myeloma. J. Clin. Invest., 1943, 22, 137.

36. Malmros, H., and Blix, G., Plasma proteins in cases with high erythrocyte sedimentation rates. Acta med. Scandinav., 1946, Supp. 170, 280.

37. Bendich, A., and Kabat, E. A., Immunochemical estimation of the rate of disappearance of transfused gamma globulin from the blood in two cases of hypoproteinemia. J. Lab. \& Clin. Med., 1949, 34, 1066.

38. Barr, D. P., Reader, G. G., and Wheeler, C. H., Cryoglobulinemia. I. Report of two cases with discussion of clinical manifestations, incidence and significance. Ann. Int. Med., 1950, 32, 6.

39. Stern, K. G., Laszlo, D., and Krakauer, J. S., Physical chemical studies on sera of myeloma patients. Cancer Res., 1949, 9, 614. 